\title{
THE EFFECT OF FIRM PERFORMANCE, LEVERAGE, FIRM SIZE, AND FIRM GROWTH ON AGENCY COST OF TRADING COMPANY IN INDONESIA, MALAYSIA, AND THAILAND: RESEARCH PERIOD OF 2009 - 2013
}

\author{
Hamidah \\ Email: hamidahsam@gmail.com \\ Ario Wicaksono \\ Email: wicaksono.ario31@gmail.com \\ Gatot Nazir Ahmad \\ Email: gatot11510@yahoo.com
}

\begin{abstract}
In this study, the author investigate the relationship of firm performance, leverage, firm size, and firm growth on the agency cost. In the company's life, there are several holders an important role in the company itself. Agency theory explains that there are two parties to a company, the agent and principal.Researcher use firm performance, leverage, firm size, and firm growth as the independent variables. Researcher use the operational expenses ratio as proxy of agency cost. The high firm performance, expected to leads the lower agency cost.Researcher use the 19 listed trading firm on Indonesia, 26 listed trading firm on Malaysia, and 29 listed trading firm on Thailand. The empirical result show varying effect on agency cost in those three countries. The result of research depends on the characteristics of each country
\end{abstract}

Keywords: Agency Cost, firm performace, leverage, firm size, firm growth 


\section{PENDAHULUAN}

Dalam kehidupan sebuah perusahaan, terdapat beberapa pemegang peranan penting dalam perusahaan itu sendiri. Menurut Manurung (2012), teori agensi menerangkan bahwa ada dua buah pihak dalam suatu perusahaan, yaitu agent dan principal. Agent merupakan pihak yang mengelola perusahaan. Berjalannya perusahaan paling besar bergantung pada agent atau tindakan agent sebagai patokan untuk berkembangnya suatu perusahaan. Oleh karenanya, agent sering menjadi perhatian berbagai pihak dalam melihat kemajuan perusahaan. Sebaliknya, pemilik perusahaan atau penyetor dana kepada perusahaan, sering disebut dengan principal. Keinginan principal yang harus dijalankan oleh agent adalah agar principal mendapatkan return atas investasi atau menyerahkan sejumlah dana ke perusahaan. Kedua belah pihak tersebut masing-masing memegang peranan penting dalam kemajuan sebuah perusahaan. Agent tidak dapat mengeluarkan keputusan-keputusan strategis bagi kemajuan perusahaan tanpa dukungan serta sokongan dana dari pihak principal. Begitu juga sebaliknya, principal tidak akan mampu sendiri menjalankan perusahaan tanpa kebijakankebijakan yang dikeluarkan oleh agent demi meningkatkan kinerja perusahaan itu sendiri.

Dalam penelitian ini, peneliti membatasi faktor yang mempengaruhi biaya keagenan (agency cost), yaitu kinerja perusahaan, ukuran perusahaan (firm size), pertumbuhan perusahaan (firm growth), dan Struktur Modal (Leverage). Kinerja perusahaan yang terus meningkat pada setiap periode, tentunya adalah sesuatu yang diharapkan oleh semua stakeholder perusahaan. Namun, belum banyak yang tahu apakah besarnya kinerja keuangan perusahaan dapat dipengaruhi oleh tingkat biaya keagenan secara signifikan. Selain itu, pada perusahaan dengan kinerja yang relatif tinggi, peran hutang jangka pendek dalam meminimalisasi biaya keagenan dapat dikatakan lemah. Hal tersebut menandakan bahwa tingginya kinerja perusahaan yang dihasilkan bisa saja dipengaruhi oleh minimnya biaya keagenan yang terjadi dalam suatu perusahaan. Karena tingginya kinerja perusahaan biasanya dibarengi dengan tingginya kualitas good corporate governance yang diterapkan oleh perusahaan tersebut. 
Jelinek dan Stuerke (2009) dalam penelitiannya menemukan bahwa tingkat hutang suatu berpengaruh positif signifikan terhadap tingkat biaya keagenan yang timbul dalam suatu perusahaan. Hal tersebut mungkin saja terjadi dikarenakan semakin tingginya tingkat hutang suatu perusahaan, maka pihak agent berusaha keras untuk melakukan pembayaran kepada pihak kreditur sementara pihak principal tetap menginginkan agar nilai saham perusahaan tersebut menjadi tinggi meskipun perusahaan berada dalam masalah yang seharusnya diselesaikan terlebih dahulu. Oleh karena itu, terjadilah asymmetric information antara kedua belah pihak yang kemudian dapat menimbulkan kenaikan biaya keagenan dalam suatu perusahaan.

Masih menurut Jelinek dan Stuerke, ukuran perusahaan berpengaruh negative signifikan terhadap biaya keagenan yang timbul pada suatu perusahaan.Kemudian, dari sisi ukuran perusahaan, ukuran perusahaan mungkin saja berpengaruh negative signifikan terhadap biaya keagenan pada perusahaan. Hal tersebut dapat terjadi karena semakin besar ukuran suatu perusahaan, semakin matang juga tingkat good corporate governance suatu perusahaan, sehingga mengakibatkan rendahnya tingkat biaya keagenan yang dapat timbul pada suatu perusahaan.

Pertumbunan perusahaan diduga berpengaruh positif terhadap biaya keagenan. Hal ini mungkin saja terjadi dikarenakan perusahaan yang memiliki tingkat pertumbuhan yang relative besar dapat menjadi ketertarikan sendiri bagi pihak agent maupun principal untuk mengambil tindakan sesuai dengan kepentingan mereka masing-masing. Sehingga, biaya keagenan yang timbul akibat terjadinya konflik kepentingan tersebut menjadi meningkat seiring dengan tingginya tingkat pertumbuhan perusahaan itu sendiri.

Penelitian ini dilakukan untuk mengetahui:

1) Apakah Kinerja Perusahaan berpengaruh signifikan terhadap Biaya Keagenan pada Perusahaan Perdagangan di Indonesia, Malaysia, dan Thailand?

2) Apakah Ukuran Perusahaan berpengaruh signifikan terhadap Biaya Keagenan pada Perusahaan Perdagangan di Indonesia, Malaysia, dan Thailand? 
3) Apakah Pertumbuhan Perusahaan berpengaruh signifikan terhadap Biaya Keagenan pada Perusahaan Perdagangan di Indonesia, Malaysia, dan Thailand?

4) Apakah Leverage berpengaruh signifikan terhadap Biaya Keagenan pada Perusahaan Perdagangan di Indonesia, Malaysia, dan Thailand?

5) Apakah Kinerja Perusahaan, Ukuran Perusahaan, Pertumbuhan Perusahaan, dan Leverage secara bersamaan berpengaruh signifikan terhadap Biaya Keagenan pada Perusahaan Perdagangan di Indonesia, Malaysia, dan Thailand?

\section{KAJIAN TEORETIK}

\section{Teori Keagenan}

Menurut Kim dan Kim (2006:18), teori keagenan berkaitan dengan konflik kepentingan antara manajer dan pemegang saham. Pemegang saham akan mendelegasikan wewenang pada manajer untuk mengambil keputusan dan ini dilakukan dengan harapan manajer akan mengikuti seluruh kehendak dari pemegang saham. Namun, tidak selamanya tujuan dari manajer selalu sejalan dengan tujuan dari pemilik perusahaan. Sebagian besar kontrol dari perusahaanperusahaan saat ini terpisah dari kepemilikan. Situasi ini memungkinkan manajer untuk bertindak sesuai kepentingan terbaik mereka, bukan demi kepentingan terbaik para pemegang saham.Dengan demikian, beberapa manajer mungkin khawatir dengan kesejahteraan mereka sendiri, seperti pendapatan mereka sendiri, kekuasaan, harga diri, dan prestise. Kesejahteraan manajer, dapat ditingkatkan dengan keputusan manajemen yang cenderung menurunkan kekayaan pemegang saham.

Untuk memastikan bahwa manajer bertindak untuk kepentingan terbaik pemegang saham, para manajer harus dipantau dan dihargai dengan insentif yang sesuai. Insentif dapat mencakup opsi saham, bonus, dan penghasilan tambahan. Pemantauan dapat dilakukan dengan meninjau penghasilan tambahan manajemen, laporan audit keuangan, dan membatasi keputusan manajemen. Masuk akal untuk mengasumsikan bahwa manajer akan melakukan tindakan yang relatif konsisten dengan maksimalisasi kekayaan pemegang saham. 


\section{Kinerja Perusahaan}

Kinerja perusahaan menurut Boughzala dan Ermine (2006:117) adalah operasi, metode, dan pendekatan untuk menilai kinerja dari sistem informasi yang ditujukan untuk mengidentifikasi peran sistem informasi dapat membantu operasi perusahaan tersebut. Masih dalam Boughzala dan Ermine (2006:117), Raymond berpendapat bahwa ada tiga definisi dari kinerja perusahaan, yaitu kinerja operasional, kinerja keuangan, dan kinerja kompetitif. Dalam buku yang sama, menurut Lorino (1991), ada peningkatan kualitas, pemendekan siklus manufaktur dan pengembangan, fungsi koordinasi yang lebih baik, jaringan operasi dan perangkat, pembelajaran metode baru, dan jenis organisasi baru yang berperan penting pada peningkatan kinerja perusahaan.

Menurut Purnama dan Setiawan (2003), pada tahun 1997, Rue dan Byard menyatakan bahwa kinerja perusahaan adalah tingkat pencapaian prestasi perusahaan yang diukur dalam bentuk hasil-hasil kerja atau performance outcome.Menurut Bloom dan Van Reenen (2002), kinerja perusahaan dapat diukur menurut dua hal, yaitu produktivitas dan nilai pasar perusahaan tersebut.

Market to book value mencerminkan estimasi investor dari premi kemampuan aliran kas perusahaan atas nilai historis investasi perusahaan. Sejauh ini, menurut mereka M/B adalah proxy untuk Tobin's q.

Market to book value $=\frac{\left(\text { total asset }- \text { total equity }+{\text { market value of equity })_{i t}}_{\text {total assets }} \text { it }\right.}{\text { to }}$

\section{Leverage}

Leverage menurut Guerard dan Schwartz (2007:224), adalah jumlah pendanaan dari luar (hutang) yang digunakan sebagai kontribusi untuk pembiayaan perusahaan itu sendiri. Penggunaan utang ini diperoleh pada prioritas pembayaran dan diberi prioritas pengembalian, hal ini memperluas potensi baik keuntungan dan kerugian dengan kepemilikan saham. 
Menurut Chandrakumarmangalam dan Govindasamy (2010), leverage adalah sumber pendanaan suatu perusahaan di mana perusahaan harus membayar biaya tetap dan pengembalian tetap dari sumber pendanaan tersebut. Leverage terdiri dari dua jenis, yaitu leverage operasional dan leverage finansial.

Menurut Brigham dan Ehrhardt (2008:567), risiko yang dihadapi oleh perusahaan merupakan faktor yang mempengaruhi keputusan tentang struktur modal. Risiko dapat dikategorikan dalam risiko bisnis (business risk) dan risiko keuangan (financial risk). Risiko bisnis (business risk) yaitu tingkat risiko terkait dengan tidak digunakannya hutang jangka panjang untuk membiayai asset perusahaan. Jika risiko bisnis makin besar, artinya rasio hutang makin kecil. Risiko keuangan (financial risk) yaitu risiko yang dihadapi para pemegang saham biasa sebagai akibat penggunaan hutang jangka panjang.

Chen et al., (2009) melakukan pengukuran leverage dengan formulasi sebagai berikut:

$$
\text { Leverage }=\frac{\text { total utang }}{\text { total aktiva }}
$$

\section{Ukuran Perusahaan}

Ukuran perusahaan menggambarkan besar kecilnya suatu perusahaan (Supriyanto dan Falikhatun, 2008). Dalam paper Lun dan Quaddus (2011), menurut Wang et al., ukuran perusahaan memegang peranan penting pada sebagian riset empirikal manajemen stratejik. Sebagian studi empiris ini berkisar antara permasalahan internal organisasi sampai dengan kerja sama antarperusahaan.

Menurut Supriyanto dan Falikhatun (2008), ukuran perusahaan dapat diukur dengan menggunakan natural logarithm dari total penjualan. Penjabaran tersebut dapat dirumuskan sebagai berikut:

$$
\text { Ukuran Perusahaan }=\ln (\text { total sales })
$$




\section{Pertumbuhan Perusahaan}

Pertumbuhan perusahaan menurut Hasan et.al. (2014), adalah pertumbuhan penjualan atau pendapatan yang diukur dari perubahan penjualan setiap tahunnya. Sehingga, semakin besar nilai kenaikan penjualan suatu perusahaan setiap tahunnya, maka makin besar pertumbuhan yang terjadi pada suatu perusahaan. Sedangkan, Salim dan Yadav (2012) mengungkapkan bahwa pertumbuhan perusahaan dapat direpresentasikan sebagai perubahan total asset yang terjadi setiap tahunnya. Sehingga dapat dikatakan bahwa semakin besar perubahan total asset yang terjadi pada perusahaan, semakin besar juga pertumbuhan perusahaan tersebut. Penjabaran tersebut dapat dituang dalam rumus sebagai berikut:

$$
\text { Pertumbuhan Perusahaan }=\% \Delta \text { total }_{\text {asset }} \text { it-it-1}
$$

Dari uraian di atas, hipotesis yang akan diuji antara lain adalah:

H1: Kinerja perusahaan berpengaruh positif signifikan terhadap biaya keagenan perusahaan perdagangan yang listing di BEI, Bursa Efek Thailand, dan Bursa Efek Malaysia.

$\mathrm{H} 2$ : Leverage berpengaruh positif signifikan terhadap biaya keagenan perusahaan perdagangan yang listing di BEI, Bursa Efek Thailand, dan Bursa Efek Malaysia.

H3: Ukuran Perusahaanberpengaruh positif signifikan terhadap biaya keagenan perusahaan perdagangan yang listing di BEI, Bursa Efek Thailand, dan Bursa Efek Malaysia.

H4: Pertumbuhan Perusahaanberpengaruh positif signifikan terhadap biaya keagenan perusahaan perdagangan yang listing di BEI, Bursa Efek Thailand, dan Bursa Efek Malaysia.

H5: Kinerja Prusahaan, Leverage, Ukuran Perusahaan, dan Pertumbuhan Perusahaanpada model yang digunakan dalam penelitian ini berpengaruh signifikan secara statistik terhadap rasio pemanfaatan asset perusahaanperdagangan yang listing di BEI, Bursa Efek Thailand, dan Bursa Efek Malaysia. 


\section{METODE PENELITIAN}

Metode penelitian ini menggunakan metode penelitian asosiatif yaitu metode penelitian untuk mengetahui hubungan antara dua variabel atau lebih dalam model. Model regresi yang diteliti adalah sebagai berikut:

$$
Y_{i t}=\alpha+\beta_{1} \text { kinerja perusahaan }_{i t}+\beta_{2} \text { leverage }_{i t}+\beta_{3} \text { size }_{i t}+\beta_{4} \text { growt }_{i t}+e_{i t}
$$

\section{Prosedur Pengumpulan Data}

Penelitian ini menggunakan data sekunder yang diperoleh dari beberapa sumber. Informasi terkait data laporan-laporan keuangan perusahaan perdagangan yang go public untuk Negara Indonesia, Malaysia, dan Thailand diperoleh dari situs bursa efek masing-masing negara tersebut. Penelitian kepustakaan dilakukan untuk memperoleh landasan teoretis yang dapat menunjang dan dapat digunakan untuk tolok ukur pada penelitian ini.Penelitian kepustakaan ini dilakukan dengan cara membaca, menelaah, dan meneliti literatur-literatur yang tersedia seperti buku, jurnal, majalah, dan artikel yang tersedia menyangkut biaya keagenan, kinerja perusahaan, leverage, ukuran perusahaan, dan pertumbuhan perusahaan.

\section{Metode Penentuan Populasi dan Sampel}

Populasi pada penelitian ini adalah seluruh perusahaan yang listing di BEI, TSE, dan MYX pada tahun 2009-2013 dengan menggunakan data panel pada penelitian. Sementara itu, sampel dipilih dengan metode purposive sampling yaitu teknik penentuan sampel dengan pertimbangan atau dengan kriteria pemilihan tertentu. Adapun kriteria-kriteria tersebut adalah:

1. Perusahaan perdagangan yang listing di BEI, TSE, dan MYX

2. Secara konsisten mempublikasikan laporan keuangan setiap tahunnya

Berdasarkan kriteria tersebut di atas, maka terpilihlah sampel sebanyak 19 perusahaan perdagangan yang listing di BEI, 26 perusahaan perdagangan di TSE, dan 29 perusahaan perdagangan di MYX dari tahun 2009-2013. 


\section{Metode Analisis}

Metode analisis yang digunakan dalam penelitian ini adalah metode analisis regresi liner berganda (multiple regression) metode ordinary least square (OLS). Penelitian ini juga menggunakan uji hipotesis, yaitu uji- $t$ dan uji-F

\section{HASIL DAN PEMBAHASAN}

\section{Uji Normalitas}

Uji normalitas ini dilakukan untuk mengetahui apakah data-data yang diperoleh sebagai variabel-variabel terpilih tersebut berdistribusi normal atau tidak (Prabawati, 2010:53). Hasil yang diperoleh adalah untuk nilai signifikansi normalitas dengan Kolmogorov-Smirnov setelah satu kali transformasi data untuk perusahaan perdagangan Indonesia dengan variabel biaya keagenan, kinerja perusahaan, leverage, ukuran perusahaan, dan pertumbuhan perusahaan berturutturut adalah 0,$334 ; 0,727 ; 0,053 ; 0,181$; dan 0,240 sehingga dapat dikatakan bahwa data-data yang telah ditransformasi tersebut berdistribusi normal.

Sesuai dengan Tabel 1, untuk nilai signifikansi normalitas dengan Kolmogorov-Smirnov setelah satu kali transformasi data untuk perusahaan perdagangan Malaysia dengan variabel biaya keagenan, kinerja perusahaan, leverage, ukuran perusahaan, dan pertumbuhan perusahaan berturut-turut adalah 0,266; 0,180;0,120;0,360; dan 0,071 sehingga dapat dikatakan bahwa data-data yang telah ditransformasi tersebut berdistribusi normal.

Kemudian untuk nilai signifikansi normalitas dengan KolmogorovSmirnov setelah satu kali transformasi data untuk perusahaan perdagangan Thailand dengan variabel biaya keagenan, kinerja perusahaan, leverage, ukuran perusahaan, dan pertumbuhan perusahaan berturut-turut adalah 0,074;0,499; 0,270; 0,104; dan 0,119 sehingga dapat dikatakan bahwa data-data yang telah ditransformasi tersebut berdistribusi normal. 
Tabel 1: Uji Kolmogorov-Smirnov pada Perusahaan Perdagangan 3 Negara

Setelah Transformasi

\begin{tabular}{lllllll}
\hline \multirow{1}{*}{ Negara } & \multicolumn{2}{c}{ Indonesia } & \multicolumn{2}{c}{ Malaysia } & \multicolumn{2}{c}{ Thailand } \\
\cline { 2 - 7 } & K-S Z & Asymp.Sig. & K-S Z & Asymp.Sig. & K-S Z & Asymp.Sig. \\
Agency & 0,982 & $0,334^{*}$ & 1,004 & $0,266^{*}$ & 3,324 & $0,074^{*}$ \\
Performance & 0,691 & $0,727^{*}$ & 1,097 & $0,180^{*}$ & 0,828 & $0,499^{*}$ \\
Leverage & 1,346 & $0,053^{*}$ & 1,593 & $0,120^{*}$ & 1,000 & $0,270^{*}$ \\
Size & 1,096 & $0,181^{*}$ & 0,918 & $0,368^{*}$ & 2,958 & $0,104^{*}$ \\
& & & & & & \\
Growth & 1,489 & $0,240^{*}$ & 1,292 & $0,071^{*}$ & 1,188 & $0,119^{*}$ \\
\hline
\end{tabular}

Sumber: data diolah oleh peneliti

\section{Uji Multikolinieritas}

Multikolinieritas dapat didefinisikan sebagai hubungan linier antarvariabel bebas (Nachrowi dan Usman, 2006: 95). Hal ini disebabkan oleh adanya korelasi antara variabel-variabel bebas dalam suatu model. Terlihat pada tabel 2, 3, dan 4 yang merupakan tabel korelasi antarvariabel dari ketiga negara, tidak ada koefisien korelasi antarvariabel yang lebih besar dari 0,8 atau mendekati 1 , dengan demikian terdapat sifat multikolinieritas yang kecil antarvariabel pada penelitian ini sehingga penelitian dapat dilanjutkan.

Tabel 2: Korelasi Antarvariabel Perusahaan Perdagangan Indonesia

\begin{tabular}{lllll}
\hline & Performance & Leverage & Size & Growth \\
\hline Performance & 1 & & & \\
Leverage & $-0,141794$ & 1 & & \\
Size & 0,273782 & 0,318972 & 1 & 1 \\
Growth & 0,022708 & $-0,083806$ & $-0,167927$ & 1 \\
\hline \multicolumn{2}{r}{ Sumber:data diolah oleh peneliti } & &
\end{tabular}

Tabel 3: Korelasi Antarvariabel Perusahaan Perdagangan Malaysia

\begin{tabular}{lllll}
\hline & Performance & Leverage & Size & Growth \\
\hline Performance & 1 & & & \\
Leverage & 0,309189 & 1 & & \\
Size & $-0,292640$ & $-0,018515$ & 1 & 1 \\
Growth & $-0,067789$ & $-0,071899$ & 0,134481 & 1 \\
\hline \multicolumn{2}{r}{ Sumber:data diolah oleh peneliti } & &
\end{tabular}

Tabel 4: Korelasi Antarvariabel Perusahaan Perdagangan Thailand

\begin{tabular}{lllll}
\hline & Performance & Leverage & Size & Growth \\
\hline Performance & 1 & & & \\
\hline
\end{tabular}




\begin{tabular}{lllll}
\hline Leverage & 0,292307 & 1 & & \\
Size & 0,347211 & 0,048984 & 1 & \\
Growth & 0,142327 & 0,238324 & 0,006858 & 1 \\
\hline
\end{tabular}

Sumber:data diolah oleh peneliti

\section{Uji- $t$}

Tabel 5 menunjukkan nilai t-statistic dan probabilitas $t$-statistic dari masing-masing koefisien pada variabel-variabel yang telah diregresi pada semua uji regresi linier. Nilai yang ditulis di atas adalah nilai dari koefisien regresi, sedangkan nilai yang tertulis dalam kurung merupakan nilai dari $t$-statistic.

Pada perusahaan perdagangan Indonesia, dapat dilihat bahwa kinerja perusahaan berpengaruh positif signifikan terhadap biaya keagenan. Leverage dan pertumbuhan perusahaan berpengaruh positif tidak signifikan terhadap biaya keagenan yang mungkin timbul pada suat perusahaan. Selebihnya, ukuran perusahaan berpengaruh negatif tidak signifikan terhadap biaya keagenan.

Untuk perusahaan perdagangan Malaysia, dapat dilihat bahwa kinerja perusahaan dan pertumbuhan perusahaan justru berpengaruh negatif signifikan terhadap biaya keagenan yang mungkin ditimbulkan oleh suatu perusahaan. Leverage berpengaruh positif signifikan terhadap biaya keagenan pada perusahaan perdagangan di Malaysia dan pada perusahaan perdagangan Malaysia, ukuran perusahaan berpengaruh positif tidak signifikan terhadap biaya keagenan.

Kemudian untuk perusahaan perdagangan Thailand, dapat dilihat bahwa kinerja perusahaan berpengaruh positif signifikan terhadap biaya keagenan pada suatu perusahaan. Sedangkan leverage, ukuran perusahaan, dan pertumbuhan perusahaan berpengaruh positif tidak signifikan terhadap biaya keagenan yang timbul pada suatu perusahaan.

Untuk kasus perusahaan perdagangan di Indonesia dan Thailand, di mana kinerja perusahaan berpengaruh postif signifikan terhadap biaya keagenan yang mungkin ditimbulkan oleh perusahaan, sesuai dengan hasil penelitian dari Florackis \& Ozkan (2008). Kinerja perusahaan dimungkinkan berpengaruh positif signifikan terhadap biaya keagenan dikarenakan semakin tinggi kinerja suatu perusahaan, maka stakeholder-stakeholder terutama pihak principal dalam 
perusahaan tersebut cenderung memanfaatkan keuntungan yang didapatkan oleh perusahaan tersebut untuk memenuhi kepentingan pribadi sehingga biaya keagenan yang ditimbulkan pun semakin besar.

Rasio hutang atau leverage perusahaan perdagangan di Indonesia dan Thailand memiliki karakteristik yang sama dalam penelitian ini. Karekteristik yang dimaksud adalah, leverage berpengaruh positif tidak signifikan terhadap biaya keagenan yang mungkin ditimbulkan pada perusahaan.

Sedangkan pada perusahaan perdagangan Malaysia, leverage berpengaruh positif signifikan terhadap biaya keagenan pada perusahaan. Pengaruh positif signifikan rasio hutang terhadap biaya keagenan sesuai dengan hasil penelitian McKnight dan Weir (2009), serta Li dan Cui (2003). Menurut mereka, semakin tinggi hutang yang dimiliki oleh suatu perusahaan kepada pihak ketiga, maka dimungkinkan terjadinya ketidakefektifan perusahaan dalam mengelola pengeluaran bebannya hingga terkonversi menjadi penjualan. Sehingga dapat dikatakan bahwa semakin tinggi tingkat hutang suatu perusahaan, maka semakin tinggi juga biaya keagenan yang timbul pada perusahaan tersebut. Hal tersebut berpengaruh secara signifikan secara statistik pada perusahaan perdagangan Malaysia.

Kemudian masih dalam tabel 5, dapat dilihat bahwa ukuran perusahaan berpengaruh positif tidak signifikan terhadap biaya keagenan perusahaan pada perusahaan perdagangan di Malaysia, dan Thailand. Sedangkan untuk perusahaan perdagangan Indonesia, terdapat pengaruh negatif tidak signifikan. Hal ini sesuai dengan hasil penelitian dari Li dan Cui (2003), serta Fauzi dan Locke (2012). 
Tabel 5: Hasil Regresi Linier

\begin{tabular}{lccc}
\hline \multicolumn{1}{c}{ Negara } & Indonesia & Malaysia & Thailand \\
\cline { 1 - 1 } Variabel & & & \\
Intercept & $-0,133$ & $-3,612$ & $-1,3$ \\
& $(0,9196)$ & $(0,000)^{* * *}$ & $(0,371)$ \\
Performance $_{\boldsymbol{t}}$ & 2,435 & $-0,9318$ & 2,545 \\
& $(0,0409)^{* *}$ & $(0,000)^{* * *}$ & $(0,0065)^{* * *}$ \\
Leverage $_{\boldsymbol{t}}$ & 0,323620 & 1,9317 & 0,527 \\
& $(0,9154)$ & $(0,000)^{* * *}$ & $(0,224)$ \\
Size $_{\boldsymbol{t}}$ & $-0,1391$ & 0,3613 & 0,192 \\
& $(0,7339)$ & $(0,6466)$ & $(0,861)$ \\
Growth $_{\boldsymbol{t}}$ & 0,0088 & $-0,218$ & 0,0054 \\
& $(0,9960)$ & $(0,0672)^{*}$ & $(0,845)$ \\
Adjusted $\boldsymbol{R}^{2}$ & 0,642 & 0,390 & 0,68 \\
F-Statistics & 1,14 & 13,35 & 3,106 \\
Prob.F-Statistics $^{*}$ & 0,340 & $0,000 * * *$ & $0,018 * *$ \\
*signifikan pada level 10\% & & \\
**signifikan pada level 5\% & & \\
*** signifikan pada level 11\% & & \\
Sumber: Data diolah oleh Peneliti & &
\end{tabular}

Pengaruh positif ukuran perusahaan terhadap biaya keagenan dapat timbul karena semakin besar ukuran suatu perusahaan, maka semakin tinggi juga kepentingan pihak principal dan pihak agent. Hal ini lah yang menyebabkan gap antar kedua komponen penting perusahaan tersebut semakin besar. Sehingga biaya keagenan yang ditimbulkan oleh perusahaan tersebut menjadi semakin besar. Sedangkan pengaruh negatif ukuran perusahaan terhadap biaya keagenan yang dapat timbul pada perusahaan dimungkinkan terjadi karena semakin tinggi ukuran suatu perusahaan yang dalam hal ini ditandai dengan meningkatnya penjualan, maka semakin tinggi juga kedewasaan yang timbul pada perusahaan tersebut. Sehingga yang terjadi adalah para pemegang kepentingan baik pihak agency maupun pihak principal dapat bekerja bersama untuk membuat kinerja perusahaan lebih meningkat dibanding tahun-tahun sebelumnya.

Selanjutnya dapat dilihat bahwa terdapat pengaruh yang bersifat positif tidak signifikan antara pertumbuhan perusahaan terhadap biaya keagenan pada negara Indonesia dan Thailand. Hal ini dimungkinkan terjadi karena semakin semakin tinggi pertumbuhan suatu perusahaan, maka semakin tinggi juga kepentingan yang ada pada pihak principal dan agent yang memicu semakin 
besarnya nilai dari biaya keagenan dari perusahaan itu sendiri. Namun, hal itu tidak berpengaruh secara signifikan pada perusahaan perdagangan di Thailand.

Sedangkan untuk perusahaan perdagangan Malaysia, terdapat pengaruh negatif signifikan antara pertumbuhan perusahaan dengan biaya keagenan yang mungkin terjadi dalam suatu perusahaan. Hal ini sesuai dengan Florackis dan Ozkan (2008) yang menemukan bukti empiris bahwa terdapat pengaruh negatif dan signifikan yang terjadi antara pertumbuhan perusahaan terhadap biaya keagenan.

Pengaruh negatif signifikan yang terjadi antara pertumbuhan perusahaan terhadap biaya keagenan dimungkinkan terjadi dikarenakan semakin pesatnya pertumbuhan yang terjadi pada sebuah perusahaan, dapat mengindikasikan kematangan dan kesadaran pada stakeholder pada perusahaan tersebut, dalam hal ini termasuk pihak agency dan pihak principal, untuk bersama-sama membuat jalan bagi perusahaan untuk semakin berkembang. Sehingga biaya keagenan yang ditimbulkan pun akan semakin berkurang seiring dengan pesatnya pertumbuhan suatu perusahaan.

\section{KESIMPULAN DAN SARAN}

\section{Kesimpulan}

Kesimpulan yang dapat diambil dari hasil penelitian ini diuraikan berdasarkan negara-negara yang menjadi objek penelitian, dalam hal ini Indonesia, Malaysia, dan Thailand.

1. Kesimpulan untuk perusahaan perdagangan Indonesia

a. Kinerja perusahaan tidak berpengaruh positif signifikan terhadap biaya keagenan pada perusahaan perdagangan di Indonesia

b. Leverage tidak berpengaruh positif signifikan terhadap biaya keagenan pada perusahaan perdagangan di Indonesia

c. Ukuran Perusahaan tidak berpengaruh positif signifikan terhadap biaya keagenan pada perusahaan perdagangan di Indonesia 
d. Pertumbuhan perusahaan tidak berpengaruh positif signifikan terhadap biaya keagenan pada perusahaan perdagangan di Indonesia

e. Secara stimultan atau bersama-sama, kinerja perusahaan, leverage, ukuran perusahaan, dan pertumbuhan perusahaan berpengaruh positif signifikan terhadap biaya keagenan pada perusahaan perdagangan di Indonesia.

2. Kesimpulan untuk perusahaan perdagangan Malaysia

a. Kinerja perusahaan tidak berpengaruh positif signifikan terhadap biaya keagenan pada perusahaan perdagangan di Malaysia

b. Leverage berpengaruh positif signifikan terhadap biaya keagenan pada perusahaan perdagangan di Malaysia

c. Ukuran perusahaan tidak berpengaruh positif signifikan terhadap biaya keagenan pada perusahaan perdagangan di Malaysia

d. Pertumbuhan perusahaan tidak berpengaruh positif signifikan terhadap biaya keagenan pada perusahaan perdagangan di Malaysia

e. Secara stimultan atau bersama-sama, kinerja perusahaan, leverage, ukuran perusahaan, dan pertumbuhan perusahaan berpengaruh positif signifikan terhadap biaya keagenan pada perusahaan perdagangan di Malaysia.

3. Kesimpulan untuk perusahaan perdagangan Thailand

a. Kinerja perusahaan berpengaruh positif signifikan terhadap biaya keagenan pada perusahaan perdagangan di Thailand

b. Leverage tidak berpengaruh positif signifikan terhadap biaya keagenan pada perusahaan perdagangan di Thailand

c. Ukuran perusahaan tidak berpengaruh positif signifikan terhadap biaya keagenan pada perusahaan perdagangan di Thailand

d. Pertumbuhan perusahaan tidak berpengaruh positif signifikan terhadap biaya keagenan pada perusahaan perdagangan di Thailand 
e. Secara stimultan atau bersama-sama, kinerja perusahaan, leverage, ukuran perusahaan, dan pertumbuhan perusahaan berpengaruh positif signifikan terhadap biaya keagenan pada perusahaan perdagangan di Thailand.

\section{Saran}

Saran-saran yang dapat diberikan oleh peneliti untuk pihak investor, perusahaan, dan juga untuk peneliti selanjutnya adalah:

1. Investor, perusahaan yang memiliki kriteria perusahaan yang memiliki Good Corporate Governance (GCG) atau tata kelola perusahaan yang baik. Salah satu indikator perusahaan yang memiliki GCG yang baik adalah rendahnya biaya keagenan yang terjadi pada perusahaan tersebut. Oleh karena itu, investor sudah seharusnya memperhitungkan biaya keagenan yang kemungkinan dapat terjadi pada suatu perusahaan sebelum menanamkan investasi pada perusahaan tersebut. Biaya keagenan yang rendah dianggap merepresentasikan perusahaan tersebut memiliki tata kelola yang baik sehingga perusahaan tersebut dapat melakukan efisiensi dalam mengkonversi biaya-biaya yang timbul menjadi keuntungan bagi perusahaan yang kemudian dapat meningkatkan nilai saham yang berujung pada kesejahteraan investor. Selama ini, kebanyakan investor hanya mempertimbangkan penanaman investasi dari segi fundamental dan teknikal dari nilai saham perusahaan tersebut. Jika investor melihat dari sisi internal tata kelola perusahaan, termsuk mempertimbangkan tinggi rendahnya biaya keagenan pada suatu perusahaan. Tentunya penilaian dan pertimbangan terhadap suatu investasi akan lebih mendetil, mendalam, dan lebih akurat.

2. Perusahaan perdagangan yang menjadi objek penelitian, perusahaanperusahaan diharapkan mampu mengambil kebijakan dan mensinergiskan antara kepentingan manajer dan kepentingan pemegang saham, karena kinerja perusahaan akan berpengaruh terhadap biaya keagenan yang terjadi antara pemegang saham dan manajer eksekutif pada perusahaan tersebut. Karena dalam penelitian ini, secara empiris terbukti bahwa terdapat pengaruh 
signifikan kinerja perusahaan terhadap biaya keagenan yang mungkin terjadi pada suatu perusahaan. Hendaknya para stakeholder perusahaan yaitu pihak principal dan agent tidak serta merta memanfaatkan momen tinggi atau rendahnya kinerja perusahaan untuk mengambil untung pribadi. Melainkan memanfaatkan momen tersebut untuk kesejahteraan bersama perusahaan. Hal tersebut akan lebih menstimulasi kinerja perusahaan ke arah yang lebih baik dan memperkecil gap yang terjadi antara pihak principal dengan agent.

3. Peneliti selanjutnya, dalam penelitian ini masih banyak terdapat kekurangan. Oleh karena itu, diharapkan peneliti selanjutnya, terutama yang meneliti terkait kinerja perusahaan leverage, ukuran perusahaan, dan pertumbuhan perusahaan, lebih memperbanyak sampel dalam penelitian serta memperbanyak variabel-variabel yang mungkin menyebabkan atau mempengaruhi biaya keagenan itu sendiri. Sehingga hasil diharapkan akan lebih akurat. Peneliti selanjutnya juga dapat melakukan uji ketahanan (robustness) pada model regresi dengan cara memperbanyak proxy untuk pengukuran biaya keagenan seperti menggunakan proxy rasio pemanfaatan aset.

\section{DAFTAR PUSTAKA}

Bamberg, Gunter and Klaus Spremann, 1987. Agency Theory, Information, and Incentives. Heidelberg, Germany: Springer-Verlag Berlin.

Bloom, Nicholas and John Van Reenen, 2002. Patents, Real Options And Firm Performance. The Economic Journal, vol.112, p.C97-C116.

Boughzala, Imed and Jean-Louis Ermine, 2006. Trends in Enterprise Knowledge Management. London, UK: ISTE Ltd.

Brigham, Eugene F., and Michael C. Ehrhardt, 2008.Financial Management: Theory and Practice Twelfth Edition. OH, USA: Thomson South-Western. Chandrakumarmangalam, S., and P. Govindasamy, 2010."Leverage” - An Analysis and its Impact on Profitability with Reference to Selected Cement 
Companies in India.European Journal of Economics, Finance and Administrative Sciences, Issue 27, p.53-66.

Chen,Hsiang-Lan; Hsiu-Chuan Lee; Cheng-Yi Chien; and Yen-Sheng Huang, 2009. R\&D Investment, Assets in Place, Employee Stock Bonus and Firm Performance. International Research Journal of Finance and Economics, Issue 31, p. 41-54.

Fauzi, Fitriya and Stuart Locke, 2012. Do Agency Costs really matter? A Nonlinear Approach of Panel Data. Asian Journal of Finance and Accounting, vol.4, issue 1,p.359-176

Florackis, Christostomos and Aydin Ozkan, 2008. Agency Costs and corporate Governance Mechanism: Evidence for UK Firms. International Journal of Managerial Finance, vol.4 issue 1,p.37-59

Guerard, John B. Jr., and Ely Schwartz, 2007. Quantitative Corporate Finance. New York, USA: Springer.

Hasan, Md Bokhtiar; A.F.M.Mainul Ahsan; Md.Afzalur Rahaman; and Md.Nurul Alam, 2014. Influence of Capital Stucture on Firm Performance: Evidence from Bangladesh. International Journal of Business and Management, vol.9, issue 5. p184-194

Jelinek, Kate and Pamela S.Stuerke, 2009. The Nonlinear relation between Agency Cost and Managerial Equity Ownership. International Journal of Managerial Finance, Vol 5, Issue 2, p.156-178

Jensen, Michael C., and William H.Meckling, 1976. Theory of The Firm: Managerial Behavior, Agency Cost, and Ownership Structure. Journal of Financial Economics, vol.3, p.305-360.

Karpoff, Jonatan M.; M. Wayne Marr, Jr.; and Morris G. Danielson, 1994. Corporate Governance and Firm Performance. Virginia, USA: The Research Foundation of The Institute of Chartered Financial Analysts

Kim, Suk and Seung H. Kim, 2006. Global Corporate Finance Sixth Edition. Malden, USA: Blackwell Publishing 
Li, Hongxia and Liming Cui, 2003. Empirical Study of Capital Structure on Agency Costs in Chinese Listed Firms. Nature and Science, vol.1 issue 1, p. $12-20$

Lun, Y.H. Venus and Mohammed A. Quaddus, 2011. Firm size and performance: A study on the use of electronic commerce by container transport operators in Hong Kong. Expert Systems with Applications, vol.38, p.7227-7234

Manurung, Adler Haymans, 2012. Teori Keuangan Perusahaan. Jakarta: PT Adler Manurung Press.

McKnight, Phillip J., and Charlie Weir, 2009. Agency Costs, corporate governance mechanisms, and ownership structure in large UK publicity quoted companies: A panel data analysis. The Quarterly Review of Economics and Finance, vol.49, 139-158

Meng, R.; Xiangdong Ning, Xianming Zhou; and Hongquan Zhu, 2010. Do ESOPs enhance firm performance? Evidence from China's reform experiment.Journal of Bank and Finance, p. 1-11.

Nachrowi, Nachrowi D and Hardius Usman, 2006. Pendekatan Populer dan Praktis Ekonometrika untuk Analisis Ekonomi dan Keuangan. Jakarta: Lembaga Penerbit Fakultas Ekonomi Universitas Indonesia.

Nugroho, M. Taufan, 2009. Analisis Faktor-Faktor YangMempengaruhi Struktur Modal Pada PerusahaanManufaktur Yang Terdaftar Di Bursa Efek Indonesia.Fakultas Ekonomi Universitas Muhammadiyah Surakarta.

Nuzula, Nila Firdausi, 2010. Struktur Modal (Capital Structure), Bahan Ajar Manajemen Keuangan II.

Peng, Mike W., 2004. Outside Directors And Firm Performance During Institutional Transitions. Strategic Management Journal, vol.25, p. 453-471.

Purnama, Nursya'bani and Hery Setiawan, 2003. Analisis Pengaruh SumberSumber Keunggulan Bersaing Bidang Pemasaran Terhadap Kinerja Perusahaan Manufaktur Di Indonesia. Jurnal Siasat Bisnis, vol.2, p.105130. 
Salim, Mahfuzah and Raj Yadav, 2012. Capital Structure and Firm Performance: Evidence from Malaysian Listed Companies. International Congress on Interdisciplinary Business and Social Science 2012, issue 65, p.156-166.

Supriyanto, Eko and Falikhatun, 2008. Pengaruh Tangibility, Pertumbuhan Penjualan, dan Ukuran Perusahaan Terhadap Struktur Keuangan. Jurnal Akuntansi dan Bisnis, vol.10, no.1, p.13-22.

Wellalage, Nirosha Hewa and Stuart Locke, 2012. An Empirical Investigation of Agecy Costs and Ownership Structure in Unlisted Small Business. New Zealand Journal of Applied Business Research, vol.10 issue 2, p.37-48 